detract from the value of a book which is brilliantly written, well produced and admirably illustrated. The student, the house surgeon and the general practitioner will find it specially valuable, and the registrar and the consultant will learn a lot from it. All those who have to deal with fractures-even those living in Liverpool and in Whitechapel-will wish to congratulate Professor Perkins on a great achievement.

\section{APPLIED PHYSIOLOGY OF THE EYE}

By H. Willoughiy Lyle, M.D., F.R.C.S., assisted by T. Keith LYLE, C.B.E., M.A., M.D., M.Chir., M.R.C.P., F.R.C.S. Pp. vii + 34I, with 32 diagrams. London: Baillière, Tindall \& Cox. Ltd. . 1958. 45 s.

This book encompasses physiology of the eye and its related structures. Great stress is laid on the neurophysiology and its clinical application, and is thus of not inconsiderable value to the practising ophthalmologist and student of ophthalmology. Unfortunately a section on colour vision is not included in the text. There are useful diagrammatic cross-sections of the brain stem not available in other textbooks of ophthalmic physiology. A most welcome inclusion in the text is a list of the Greek derivation of important words and ophthalmological eponyms.

This is a textbook which will gain its place amongst contemporary books on the physiology of the eve.

\section{THE MATRIX OF MEDICINE}

Ed. by Nicolas Mallesor, M.D., M.R.C.P. Pp. xviii +234 . London: Pitman Medical Publishing Co. Ltd. I 958 . 45 s.

This is a collection of essays about how the work of doctors should be related to the community in which they live, the whole being an elaboration of the opening phrase in the introduction: 'Medicine is a part of society.'

A lay member of a hospital committee, an intending social worker or a potential medical student in the sixth form at school will find the book stimulating. The idea behind the book is excellent, but this attempt at putting the idea across is unduly expensive at $45 \mathrm{~s}$.

\section{THE STORY OF HEART DISEASE}

By Terence East, M.A., D.M.(Oxon). Pp. 148, with I I plates. Farnham: Wm. Dawson \& Sons Ltd. I 958 . 30 s.

The FitzPatrick Lectures given before the Royal College of Physicians in 1956 and 1957 are here published in book form. They make a scholarly and entertaining introduction to the history cardiology and the four lectures deal successity with diagnosis, lessons of the dead house, the corronary circulation and failure of the circulation.

Dr. East, in each lecture, traces the evolution of his subject, from the first slow and fumbling s, in ancient and medieval times, through the obsefrations of the great clinicians and pathologists of the 18th and 19th centuries to the present day. Fis story is largely told in the lives of the men tho made it and often by quotations from their writiags. $\mathrm{He}$ is singularly successful in bringing his subjeffcts to life by brief word pictures, such as that of Skeda, ' . . a whimsical bachelor who lived in fear of his tailor and so never changed the fashion of his clothess,' or by a case report, as in Dr. Bucknills's molang account of the death of Thomas Arnold of Rug y.

This book is a rich mine of information anecdote and is pleasantly produced and illustratod. It is impossible to read it without seeing the subtêct in better perspective and feeling a new respect कुor ' those who were before us.'

\section{THE INTERFERENCE MICROSCOPE INO BIOLOGICAL RESEARCH}

By Arthur J. Hale, M.B., Ch.B., Ph.D. Pp. xh

I I 4, with 95 diagrams. Edinburgh: E. \& $S$. Livingstone Ltd. I 958 . 20 s.

Although interference microscopes of man ferent patterns have been proposed and indeed rage, it is only recently that reliable, relatively sim le commercial models have become available. Alre they have been applied in many biological fieldg from the growth of yeasts and bacteria to ơne estimation of enzymes. This book, by a logical consideration of the principles, value and limitations of the method and present instruments, fully succeeds in its aim of enabling the general worer to assess the application of the technique to particular field.

\section{INTRODUCTION TO BIOSTATISTICS}

By Hugh Bancroft, Ph.D. Pp. $x+210$, with ${ }_{37}^{\circ}$ diagrams. London: Cassell \& Co. Ltd. 198 $42 s$.

The increasing importance of a knowledge Oof statistics in the practice of scientific medicine makes the appearance of a new introductory book on the subject a matter of some importance. Many of $\mathcal{W I}^{\mathrm{W}}$ rather resent the idea of handing our material, loek, stock and barrel, over to a specialist statistician $\mathbb{P r}$ analysis and would prefer to acquire a basic work knowledge ourselves and consult with the specialist for advice when in difficulty.

This book fails to live up to early promioge. After several very practical chapters on charts and graphs, it explains the really basic business If $_{1}$ 